\title{
The Transformation of Noken Papua: Understanding the Dynamics of Noken's Commodification as the Impact of UNESCO's Heritage Recognition
}

\author{
Alice Salhuteru, ${ }^{1}$ Fred Keith Hutubessy ${ }^{2 *}$ \\ 1, 2 Universitas Kristen Satya Wacana, Salatiga - Indonesia
}

\begin{abstract}
This research was motivated by previous studies that discussed Noken from various points of view but did not examine aspects of the commodification of Noken as an implication of the world heritage label from UNESCO. Noken is a native Papuan knit bag that has high cultural values, sacred entity, and a source of life; as container for carrying garden products and animal hunting products. Noken is also a form of maturity initiation, Papuan woman who can knit noken may enter the marriage phase. Applying the qualitative method, with observations and interviews with women knitting and selling it in Jayapura as informants, this study found that firstly, Noken had undergone massive economic commodification, started with UNESCO's recognition of inherited noken as intangible, which led to more and more traded noken. Secondly, noken has transformed values, especially about the noken value that animates them. The transformation of values in noken is a necessity in the dynamics of the social, economic, and cultural changes of the Papuan. Thirdly, by knitting and selling it, they are trying to preserve the sacred value of noken, also as a strategy to survive economically in encountering the impact of the capitalist system.
\end{abstract}

Penelitian ini dilatarbelakangi oleh penelitian-penelitian sebelumnya yang membahas noken dari berbagai sudut pandang, namun tidak mengkaji aspek komodifikasi noken sebagai implikasi label warisan dunia dari UNESCO. Noken adalah tas rajut asli Papua yang memiliki nilai budaya tinggi, benda sakral, dan sumber kehidupan, yaitu sebagai wadah untuk membawa hasil bumi dan binatang buruan. Noken juga merupakan salah satu tanda kedewasaan. Perempuan Papua yang sudah bisa merajut noken, boleh memasuki fase pernikahan. Dengan menggunakan metode kualitatif, dengan observasi dan wawancara kepada perempuan yang merajut dan menjualnya di Jayapura sebagai informan, penelitian ini menemukan bahwa: pertama, Noken telah mengalami komodifikasi ekonomi secara masif, sejak adanya pengakuan UNESCO terhadap noken sebagai warisan budaya tak benda, yang menyebabkan semakin banyak memperdagangkan noken. Kedua, noken telah mengalami transformasi nilai, terutama tentang nilai noken yang menjiwainya. Transformasi nilai noken merupakan keniscayaan dalam dinamika perubahan sosial, ekonomi, dan budaya masyarakat Papua. Ketiga, dengan merajut dan menjualnya, mereka berusaha melestarikan nilai sakral noken, dan juga sebagai strategi untuk bertahan hidup secara ekonomi dalam menghadapi dampak sistem kapitalis.

Keywords: noken; cultural heritage; commodification; transformation; Papua

*Corresponding Author: Fred Keith Hutubessy (fredkeith12@gmail.com), Jl. Diponegoro No. 52-60 Salatiga 50711, Indonesia. 


\section{Introduction}

Since the Ministry of Culture and Tourism proposed the noken to UNESCO, it has accepted as an intangible cultural heritage in the world from Indonesia. This acceptance aims to internationally protect and recognize noken as a local Papuan identity (Pekei 2013). Anthropologically and sociologically speaking, it generally integrated with the Papuan identity, contain a lot of philosophical values of life, and becomes a media to connecting them, both individuals and groups (Januar 2017). One of them is the Papuan in highland, which generally uses the noken as a place to collect prey, plantation products, and even functioned as the baby carrier when they move from one area to another area. The field observation found this similar method also appeared by the highland community who migrated to Jayapura.

Furthermore, the UNESCO recognition has formed the new accumulation of noken's identities, those are, the local identity of Papua and Indonesian national identity (Marit and Warami 2015). Interestingly, according to the data we found, there are increasing numbers of people who use noken in their daily activities, not only for Papuans but also for non-Papuan (Juniati 2019). One of them is referring to the report Dil/wen (2019) and Ramah (2019), we will find that the Jayapura Mayor's policy requires the use of noken for all civil servants to use it, as well as for the society to work. This phenomenon slowly turns noken from the helpful tools in gardening and other activities into a commercial commodity. Our observational facts found that many porch shops in Jayapura City. There are a lot of Papuan women are sitting, knitting, and selling their handmade noken. Even, it also can be found in some galleries owned by non-Papuan entrepreneurs. Interestingly, the current process of trading noken does not only occur in physical spaces, between sellers and buyers but also occurs in online stores which are widely available today. On Google, for example, there are several online trade service applications tokopedia.com and bukalapak.com that provide noken as their trade commodity. Lots of explanations have strengthened our hypothesis that it is economically commodified, and slowly allows its values to be changed.

Therefore, this article aims to discover the forms of commodification in the noken itself and how it relates to the transformation of noken value nowadays for the Papuan people. Meanwhile, as far as been known, many varieties of research who wrote articles about it such as Pekei (2013), Cahyadi et al. (2013), Dekme (2015), Malak and Nugraha (2012), Januar (2017), Pratitaswari (2018), Marit (2018), Ronsumbre (2019), Syufi et al. (2019), Brauchler (2014), and Kanem and Norris (2018) from various perspectives. However, those previous articles insufficiently explore and discuss the process of co-modification and the transformation of noken values, in the Papuan community today. Thus, this article intended to complete that research gap.

This research conducted using a qualitative approach, including in-depth observations, interview documentation, and also supported by some relevant literature (Creswell 2007). This article is the result of our field research in several areas in Jayapura. As reason we chose this city, because the multi-ethnic population and also as 
a meeting point for the civil society from various regions in Indonesia. Although the quantity of migrants dominates the native population, the social and spiritual fabric of the local community has still survived until now (Baharuddin et al. 2015). The next reason is the several craftswomen groups and noken trading places in there. Meanwhile, According to research (Iek and Ratang 2020), it also explain that noken knitters are women and supported the creative economy in Jayapura City. Then, we made the on-the-spot observations and interviews with several informants such as the knitters as well as noken sellers at the shop porches, noken entrepreneurs in several galleries, and several noken customers. Furthermore, the documentation is carried out to ensure the existence of the informant and also directly shows the knitting activities done by the informants. This research is also supported by several kinds of literature that specifically explore it in Papua with the various factual data as an integral part of this article.

Conceptually, this article uses the concept of culture (Koentjaraningrat 1987, 2010; Warsito 2012) to understand how is noken as a cultural product and its sacred narrative for Papuans. Kluckhohn (1953) emphasizes that culture formed from a historical perspective, rational and irrational, as a guide for humans. Besides, culture is related to the behavior and results of human behavior that are systematically arranged in human life to help humans understand who they are, one of which is in their beliefs (Koentjaraningrat 2010).

Also, according to Warsito (2012), culture has a whole system of ideas, actions, and the results of his work by learning and influences his actions to produce cultural products, which according to Kluckhohn (1953) comes from cultural elements and also own religious aspects.

Besides, we use the concept of commodification according to Mosco $(1996,2009)$ and Weber (2005) to find out how sacred cultural products undergo value transformation. According to Mosco (2009), commodification can occur when a product has a use-value that is converted by a sale value. For him, the role of communication is significant in determining the price of production. Manufacturers will regulate the system by deciding the prices according to the way of producing goods. The concept of commodification emphasizes that communication is a medium for conveying images and symbols in goods produced. The viewpoint of Weber (2005) also emphasizes rationality as a link between religion and economy and has implications for humans to innovate logically to develop capitalism. He rejected the adherence to the doctrine of protest from Calvinism, which emphasized that a person will go to heaven when the thriving economy to succeed in the world. For him, rationality reduces the tendency of the abstract nature of religious doctrine, keeps people away from sin, and tries everything to offer God in the world.

Eventually, through the concept of culture and commodification, we focus on obtaining a synthesis to the practice of noken commodification in Jayapura City.

\section{Noken: A Sacred Cultural Narrative}

Many scholars who worked on the humanity topics explained that humans are inseparable from their culture and its aspect of dialectical. 
Kluckhohn (1953), he said that the culture has been explicit and implicit patterned through human life in their historical narratives, rational and irrational nuances that manifest and become an ethical guideline of human behavior. Koentjaraningrat $(1987,2010)$ also found that culture is not only related to the overall dimension of human behavior but also as the results of human behavior, and systematically structured in human's daily life. This suitability gives space for humans (both individual and social) to understand themselves in unity form of knowledge, belief, art, norms, and order to obliging humans to accept and do it in their social life. So basically, the culture has a whole system of ideas and actions, and the results can reach by doing the process of learning (Warsito 2012).

Furthermore, human actions as a continuation of their ideas will produce a cultural product (Koentjaraningrat 2010). It has several elements such as; (1) Cipta; which are strongly related to the mind to creating science and technology, (2) Rasa; the five senses abilities to establish an aesthetics feeling produce the "art" (3) Karsa; or the desire to perfect his life, longing for the glory and noble character of life. Then, the culture, besides everything about its social system aspect, it also consists of many physical forms, which means that the culture created by human activities, and also have the physical objects as the result of the cultural process and the action.

Moreover, on the context of cultural forms, Kluckhohn (1953) also categorizes that there are seven cultural elements such as (1) Language, (2) System of Knowledge, (3) Social Organiza- tions, (4) Living Equipment and Technological Systems, (5) Livelihood System, (6) Religiosity, and (7) Arts. According to him, those seven aspects were deeply rooted inside by the local wisdom of specific communities. This concept articulates that the element of culture as human intelligence produced through participatory experiences like knowing, understanding, and believing about something sacred. These aspects play a significant role as a "sacred entity" to strengthening their social relations among the members in the community. Thus, in all those explanations, it can be said that noken is one of that cultural products for the Papuans.

Basically, noken is owned by 250 ethnic tribes in Papua with a different name from each tribe. Some of them call it Su according to the language of the Hugula tribe, jum in the language of the Dani tribe, and sum according to the Yali tribe, agiya is spoken by the Mee tribe, Ese comes from the Asmat tribe, Dump is called the Irarutu tribe. The Serui people call it rotang, aderi, or kaketa, while the Tabi/Sentani tribe calls it kangke or koroboi. In the Ayamaru/Maybrat and Ayvat tribes, noken is called eyu or yuta. The Tehit tribe can refer to various names, such as qya qsi, qya queri, and iquiyabos. The Moi people call it kwok, and the Moli tribe called it naya (Pekei 2013).

Noken is the name of derived words: inokenson or inoken from the Biak language (Pekei 2013:32). Historically, noken has been used from ancient times and has multi-functional uses. Interestingly, each tribe in Papua has a different type of noken, both from the material, creating process, sizes, varieties, and even the diverse functions. It has shown, the diversity of noken 
culture is a part of the cultural identity of each tribe, and also reflects the overall cultural identification of the Papuan. Pekei (2013:4) deeply explained that there are five natural values of noken. First, it is a bag (container) knitted and woven from bark or leaves that are sometimes colored and decorated to fulfill the inner satisfaction of craftswomen and also the noken fans. Secondly, noken is a handicraft inherited as an element of intangible culture that guarantees people to survive by filling, storing, and carrying goods to fulfill their daily life. Third, noken is a safely place to store all items in a knitted and hand-woven container that is used by the user. Fourth, it is a place for personal, and from the stuff that has been putting into noken, people will know who the owner is. Fifth, noken is the handcraft of the Papuan indigenous People full of norms, civilized, cultured, and ethical ways of life from the ancestry era until today.

Another similar finding according to Dekme (2015) also explained that noken functioned as a container or tool for storing goods made from several materials such as bark, bamboo, pandan as leaves, and jungle orchids. According to him, the complexity of the beautiful woven product of knitting noken has attracted the attention of many ethnographers. Its beauty is in harmony with many studies that explain that noken is the result of human ideas that are processed in such a way so humans can produce their useful and meaningful tools or objects.

In terms of shape, noken has two sizes according to its function those are; Large and small-sized noken. Large nokens are used to load the crops such as tubers and vegetables, hunting catches, bring their baby, content the firewood, and also the shopping items. Unlike the large ones, small-sized noken is used to load some personal needs such as wallets, matches, areca nuts, combs, and traditional or natural medicines. The natural ingredients of noken are taken from natural materials, consisting of forest pandan leaves, coconut leaves, manduan wood, nawa trees, or the black jungle orchids, and also genemu bark (Gnemon sp.). So, noken made from natural, environmentally friendly ingredients. The making process of noken is very complicated because it never uses an automatic machine. The materials are processed, dried, and then spun into yarn to make into noken (Cahyadi et al. 2013).

In some cultural structures, noken has full of notable meanings and values such as naturalist meanings, sociological meanings, anthropological meanings, philosophical meanings, normative meanings, and psychological meanings (Bobii 2019; Pekei 2013:94). Further, noken also has a symbol of life, peace, and fertility for the people of Papua, especially in the mid-highland communities, such as the Damal, Yali, Dani, Lani, Mee, Moni, Bauzi, and several other tribes. Cahyadi and his partners (2013:6) also explained that noken has fertility values for the women, especially in the highlands areas. In the daily process, noken made by an elder or an adult woman, so the noken knitters are generally called "mama-mama Papua" (Papuan woman). Then, the process is conventionally labeled as an initiation by women in several regions in Papua, which means that those who have not been able to knit and weave the noken, the prohibited from steps forward into the marriage process (Cahyadi et al. 2013). 
In its further dynamics, our research found that women are the symbol of noken in their family. Its seen in their daily activities that women are fully responsible for the family's economic needs. Many noken traders in the traditional market also use the noken to selling their vegetables and fruits. Besides, it often used to hunt in the jungle and gardening to fulfill their daily calories. According to Takimai (interview 2019) one of our informants, the philosophy of noken is that it always filled with foods to provide strength to the human body. So, women are interpreted conventionally as noken that valued for everyone besides her.

In general, Papuan women did not only knit the noken but also produce it from its raw materials. They did it from cutting down the tree, skinning the bark, spinning into threads, and knit them together. They obtain from the skin of the genemu (Gnemon sp.). They take skin the bark from its trunk, and the leaves are sold to the market as vegetables for economic needs (Yoman, interview 2019).

Meanwhile, there is a tradition of passing on how to knit noken from mothers to their daughters. It can be said as an initiation symbol of a woman's maturity if they can make a net their own noken (Tablo, interview 2019).

"I do not think I am a Papuan woman if I cannot make noken. Even, in my opinion, women who cannot make noken cannot also get married, until they can make it with their own hands. However, time flies, this tradition has slowly begun to erode and slowly began to disappear. It bad! In the past, it was not only considered as a tool to move things. But also, its a symbol of a woman's maturity. But now, this ancestral legacy has begun to disappear" (Tablo, interview 2019).
Another interview with Ohee (interview 2019) said that today, it is quite rare to found young Papuan women who are fluent in knitting noken because they began to leave the knitting culture. According to her, women required being able to make noken, but now, they prefer to go to schools and become civil servants. She said:

"The women in the village nowadays are already lazy for working with noken again. Because (they) want to go to the higher school, knitter start to disappear" (Ohee, interview 2019).

Even worse, one of the informants said that today, the noken knitters are generally over 30s years old (Yoman, interview 2019). Another reason is due to the complexity of making noken and the difficulty of obtaining its raw materials (Takimai, interview 2019). Therefore, both of those reasons show that social changes and globalization can be very influential, reduced their interests, suppress the customary narratives, and even alienate the people from their culture. In addition to the process of initiation of maturity for women, noken also being functioned as a complementary symbol of traditional marriage ceremonies, child initiation ceremonies, tribal chief's inauguration, heirlooms, welcoming guests or new people, protecting body/self as traditional clothing, a symbol of peace after the conflict between two tribes, and also as a forum for negotiations by filling objects for a peace agreement (Pekei 2013:34).

Noken has a sacredness of Papuan. The first, the meaning of the noken function is not limited to the current view of society. Noken does not only define as objects or indigenous instruments 
of the local community, but it is a knowledge system and belief system. For example, our research shows that a woman is eligible to enter the phase of married life if she can knit noken (Tablo, interview 2019). However, if they cannot make a net, women cannot access in marriage. The knowledge of knitting noken is passed down systematically through the family as an initiation process. Although, according to Cahyadi et al. (2013), Pekei (2013), Tablo (2019), Yoman (2019), the function of noken has a significant part in sharing rituals, their meaning of noken is in the belief system, one of which through the marriage system has placed noken as a sacred being.

Secondly, we discovered that the meaning of noken as a function through life experiences also places noken as the spirit of life for them. Noken is a memory of life through their traditional practices when their parents gardened and hunted (Pekey, Tablo, and Yoman, interview 2019). Through the activity with their families, they have produced spirits by creating noken as the meaning of life. Eventually, noken is part of cultural elements, one of which, according to Kluckhohn (1953), is related to the belief system. Besides, their life experiences with noken within the family present them meaning as a living entity.

\section{Today's Commodification of Noken}

In the previous section, it has explained that noken has a strong base of sacred beliefs as a process of initiating the identity of Papuan lives. However, in its current dynamics, it consists of dual identifications. It not only symbolized Papuan identity but also has had been constructed as Indonesian identity toward the world since It has recognized as a cultural heritage by UNESCO. Interestingly, this dual identity recognizes it as a heritage because it has a sacred entity in the context of nationhood. However, on the other hand, noken has an identification of Indonesian in terms of statehood, which is fully responsible preserved it. In our opinion, this is why noken was introduced everywhere in various processions. One of them is in the process of welcoming guests who visit Papua as souvenirs in the tourist market. In simple, the problem is not only in the double identity matters but also about the massive commodification following the noken production.

According to Mosco (2009), commodification occurs when a "usable" product has turned into a "sale-able" product. In this aspect, the manufacturers design a system by determining the prices based on how things produced. Thus, the more expensive product resulted is a sign that the higher the needs of individuals and society. His explanation focuses on the communication aspect that understood as a dynamic sphere of delivering messages where the images and symbols about something produced.

That argument is in the same echo with Weber (2005) who criticized the establishment of capitalism that was solidly directed to the religious commodification by the protestant church at that time. According to him, the protestant ethics also played a significant role in economic exclusivity of the secular world. Certainly, exclusively puritans who tend to influence other people to collect their wealth through the capital process. In his standpoint, 
Weber rejected those capital practices that are his opinion, are contradicting the Christian spirit that must be antipathy to the economic profits and rewards. This argument has directly criticized the ideas of puritans that initiated the spirit of capitalism. On the other hand, Weber (2005) found that the spirit of capitalism and protestant ethics (pre-destination) is arguably related to one and another. Following the context developed by Weber, religion is not becoming a supporting factor for commodification, but rationality. Quite different from Weber, the commodification of noken signifies the spirit of capitalism but based on local beliefs. Meanwhile, the practices of commodification are related to culture. According to (Irianto 2016), it develops in the era of globalization, as well as the development of the tourism industry. This situation creates the sale and purchase of cultural objects through industrialization.

Therefore, several studies prove that noken has become a commodity from the production process to the sales process (Batlajery and Wati 2019; Dewi et al. 2018; Istiqomah, Pabalik, and Hidaya 2019; Ransta 2018; Risamasu et al. 2019). This practice applies to several areas in Papua and affecting difficulty in obtaining the materials. According to the data in Jayapura, the raw material for making noken is difficult to find now. This condition is due to the increasing demand for noken in the market. The noken entrepreneur explained that almost every time noken, knitters buy yarn in his shop (Jafar, interview 2018). For him, the mutualism symbiosis applies from time to time. Wahyudi another informant in this research said:

"Now, the price of noken from original yarns expensive quiet. Because they need more effort to get the materials, according to those noken knitters, at the time, they cannot enter the areas like Keerom or Sentani anymore. Even if they have to take it from Keerom and Sentani, they have to pay a count of 1 tree, some hundreds, even though the tree also grows in the open forest. But that is it, noken now became a business tool, so starting from the raw material, all is business. Since UNESCO recognizes noken as a cultural heritage, every region starts to develop it. Honestly, if Sentani or Keerom already produce noken, the best produce is still from the highland like Wamena or Paniai. Therefore, we choose to receive more noken from original material from Wamena and Paniai" (Wahyudi, interview 2018).

According to Pigay (interview 2019) and Tabuni (interview 2019), it is increasingly difficult to find raw materials. Therefore, the raw material for making noken finally brought from the factory materials such as silk yarn, embroidery thread, and needle. The raw materials for noken endangered because it increasingly required for creating the "authentic" noken. For Pekey and Tablo (interview 2019) to get the remaining raw materials, they sometimes walk through the far distance into the forest. They went inside the forest and bartered the materials. They bring rice, cooking oil and other primary goods, and then trade it with some trees as the raw materials for noken. This system is the same as our elders. If we do not do that, we cannot sell noken for our daily needs. We also get the material from wood craftsmen, woodcutter sometimes, the ganemu trees (Gnemon sp.) that are cutting down to bring into the market for sale.

For the manufacturing process, it is quite easy to get the orders with some specific requests by the noken customers (Badi, inteview 2018). They can order in color, size, and model as they like. The models are different in odd moments; ask to 
weave the picture of Papua Island. There are some ask for the bird of paradise or tifa (Papuan's drum). Even, some also come and asking for the Morning Star flag (Papua Flag). Some people came to ask for the color of benang raja (Moluccas flag) with the colors were red, green, white, and blue (Badi, inteview 2018). She made it depend on the request. Like last June, when there was a world cup, many of them ordered noken from wool yarn but also from the string to the color of the world cup contestants' flag. Even, there was also some order arrived with hats as well. Orders are from the end of April to the end of May. So, for one month, I receive 3 to 5 requests. This data confirms that the commodification of noken is also closely related to demand factors, aside from the difficulty of raw materials, such as the commodification statement, according to (Mosco 2009). The situation led to a demand to improve the essentialization of noken. It's acknowledged made from natural raw materials, other than yarn.

Meanwhile, the noken craftswomen in the Jayapura have some communities. One of them is in the Aniya handicraft group. This group is divided into six groups and spread along the Jayapura area. The regional such as in Angkasa, Dok V, Argapura, Bhayangkara, Abepura, and Waena which formed since February 2013. In practice. This community practice generally coordinates Papuan women as the noken knitters, especially those who sell their noken on the storefronts. This group has a long-term program like join the exhibitions in Jayapura, as well as outside Jayapura. The exhibition activities outside Jayapura are usually in cooperation with Bank Indonesia, the Ministry of Industry, and the Small and Medium Enterprises
(UMKM) in Jayapura City, and Papua Province. It aims to introduce noken widely to the audience as the original identity of the Papuan people (Dogopia, interview 2018).

Besides, the community has collaborated with the Indonesian Post Office to conduct noken online sales since 2017. Until today, they have organized the training sessions, and most of them are quite interested, in terms of time efficiency and promotion for the larger customers from people outside Papua. According to Dogopia, the former training member, she said:

"The customers who buy noken generally came from people outside Papua. Therefore, every knitter is obliged to open an account in the post office center so the transaction process can be easier. So, the Jayapura Post Office is our partner now. Proceeds from online sales are $100 \%$ belong to the knitter. For five consecutive years, Bank Indonesia has always made Technical Guidance (BIMTEK) activities. This year, it has been held from October 2-5, 2018, followed by 50 different craftswomen every year." (Dogopia, interview 2018).

Those 50 noken craftswomen are the member of Indonesian creative entrepreneurs from every region in Jayapura City. During the Technical Guidance (BIMTEK), they got guidance and have taught about how to design noken. So the price can be higher than before. According to Wahyudi (interview 2018), several of the Papuan craftswoman, who are his partners, have already participated in the training activities made by Bank Indonesia.

On the training, they were exercising to modify noken, not only in the form of head-bags or shoulder-bag but also made into a handbag, cell phone bag, including clothes. But yeah, in the 
primary ingredients that are difficult to find so, they used the factory yarn. Now, we are already establishing cooperation, we prepare the materials, and we gave them some reward for every noken they made. For the cell phone bag, 20 thousand, for a small bag of 30 thousand, the medium size was 40 thousand, and a large one was 50 thousand. Sometimes they can receive from 100 thousand to 150 thousand a day. It is for noken from the factory yarn. If our noken from wood yarn directly sold, they will sell it to us. Even, now they can make knitted shoes as well. It about the shoes, we usually accept the orders for shoes on demand because it deals with the requests from the customers in terms of color, and models. I think that is a good thing from the training they followed.

For this year, all noken knitters had many jobs to get the raw materials because noken became the main souvenir for PON 2020 (Indonesian Sports event in Papua 2020). All noken knitters must prepare their noken to used as souvenirs with various sizes and shapes. Besides, the Jayapura City Government also made noken as an alternative plastic bag that planned to take effect in February next year. The intended noken consists of original material. Therefore, it is urged that all knitters can make it from materials which represent the characteristic of 7 indigenous territories (Dogopia, interview 2018).

One of the several appealing findings is that nowadays, the pawnshop accepts noken as an item that pawned. Since November 2018, the Jayapura branch Pawnshop has received a noken pawned. The requirement is that noken is an original native Papuan noken, made by bark, and not limited to the amount pawned.
Another necessity is the same as the other, such as a photocopy of the customer's ID card.

"I know this from my niece that works at a pawnshop. So, when you have a need, instead of asking from the children, I will go with five pieces of noken to the pawnshop, and then they are pawned. When I asked niece, kid, why would noken be pawned? $\mathrm{He}$ /she says this; because noken is in the primary goods, the interest-free loan is $0 \%$. The customers merely pay 5 thousand for a loan of 500 thousand for months. The provision of money for loans adjusted to the condition of the goods is they still intact or blister. If some specified times the customers are not able to, pay they will do an open auction" (Tablo, interview 2019).

According to the data we found, the economic conditions play a significant role enable to the creation in the process of making noken after being recognized by UNESCO as world heritage. Factually, the essential values of the noken are full of sacredness from the manufacturing process to its use has been eliminated in the present. The commodification of noken results in a transformation of value that turns from contextual usabilities. Such as bringing garden produce, hunted animal and bringing baby when traveling, to another economics and profitoriented usability likes souvenirs for the tourists. In the end, these practices will lead the financial income for the craftswomen's family as a new living value nowadays.

Furthermore, the transformation of nonmaterial (philosophical) values also transforms into the mark of new livelihoods, that is, as livelihoods for survival today. For Yoman, one of the existing noken knitters, she said:

"My parents said to me that noken is the source of life. If I cannot knit the noken, it means that I cannot survive, because, from the beginning of my life, I survive because 
of noken. When my mother went to our garden, she placed me in the noken, and she keeps working while I slept it. The noken protect me every time, and sometimes, she put me right beside our garden product. So, I must able to knit the noken, not only as a sign of my maturity, but it is always with me as my life" (Yoman, interview 2019).

For us, social change implies the transformation of social life that generally moves to the modernity way of life. The social spaces must be tended to more by dynamics. Furthermore, this situation directly causes difficulties in a society to get a better job for the needs of their life. However, there is a little different for them who work as a noken knitter. They can keep working with their knitting product to fulfill their daily needs. According to Pekey (interview 2019), she remembers when she saw her mom knitted the noken, all the children everyone got one. So, if they were going to the garden, she can help her to bring the garden product back home. Those are sweet potatoes, cassava, yams, veggies, and the others. But now, she makes a different style of noken, diverse when she was child. She makes it to sell it. The rewards used to be for our daily needs. Every time she knits it, she always remembers the statement from her mother to keep learning to make noken. Someday, it will be our source of life.

Eventually, this article finds that the practice of commodification has converted noken as a pattern of the social change dynamics in culture. One of them is related to the escalating businesses of noken since UNESCO recognized it as a world heritage. Through the noken women's handcraft in Jayapura City, we discovered that they are selling to support noken as a legacy of
Papua, although they have to deal with the various demands of the market. They have obstacles for obtaining natural raw materials to make knitted noken. Therefore, they produce it with different materials. Besides, they further accommodate customer demands, such as offers for unique colors and motifs.

Meanwhile, to sustain economically, they unite in the association, including doing affiliate with several companies that empower them for training to increase their administration. However, we obtain that today's noken commodification does generate the noken to transform as a function and design, unlike the habits of traditional characters to carry out hunting and gardening activities to meet their needs. However, the value of noken has not changed, and it is still the meaning of life for them even though they produce to knit and sell noken for their everyday needs.

\section{Conclusion}

The noken transformation is a reason for developing modernization and generating a social change in Papuan society. Although noken's identity still attaches itself to Papuans until now, functionally, noken has transformed. Initially, traditional people in Papua knew noken from various cultural perspectives, and they also knew him by several names in the respective tribe. When understanding noken in the suitability of a conceptual framework, actions to produce cultural products cause humans to produce cultural products (Koentjaraningrat 1987, 2010) and also have a relationship with the belief system (Kluckhohn C 1953). Factually, from a cultural perspective, noken has a complete meaning related to ritual beliefs and 
traditions such as initiations for women, wedding rituals, welcoming guests, that originate in Papuan society (Dekme 2015; Marit 2018; Pekei 2013).

However, since UNESCO recognizes it as a world heritage, noken's identity is popularly constructed, not only belonging to the Papuans but also from Indonesia in the world. According to (Irianto 2016), due to the development of globalization and its relationship with the tourism industry, cultural products have been commodified by selling as a nominal value, which one will be financially beneficial. Even though, Weber emphasizes the religion and capitalism can become the presence of rationality in humans, simultaneously with the rise of the industrial revolution to endeavor for advantage. However, according to Mosco (2009), commodification can occur as a result of the user value become converted value into selling points. According to him, the media facilitate communication. For example, we will obtain data that are many noken businesses on several online sites. Therefore, we do not have to visit Papua to purchase noken. We doubt the factor of commodification is related to the tourism industry, especially in the context of noken, as a statement by Irianto (2016).

Several approaches remain compatible with analyzing the noken, but the difference lies in understanding the form of commodification. This study found that the value of noken has a permanent meaning in life, even though the noken function turns into a selling value. Through women who knit noken, we find that they are still knitting noken severe to maintain noken as an identity, but also trying to preserve the meaning that they exist on through experiences about noken. For them, noken is still the same thing that has meaning to their lives, even though they have to sell it to obtain ends meet. The women weaving believed that noken accompanied them to their life so that the meaning of life still adhere to their life. This fact deviates from rationality, according to Weber (2005). Through the noken context, the deep sense of the noken value has bounded rationality to benefit from economic transactions. Therefore, they knit the noken through sincere appreciation.

Conclusively, we understand noken as interconnection and communication between the Papuan women and the forest. The reproduction of Papuan women's knowledge in creating noken depends on the availability of natural materials. If the forest is damaged, it will disrupt the cycle of the wisdom of Papuan women. Our data also reveals that the impact of noken commodification causes considerable demand. Whereas, they have difficulty obtaining natural raw materials because the consequence of commodification causes them to pay more to get materials, also a result of deforestation generating fewer forest products. Therefore, the primary outcome is labeling noken as an intangible world heritage is stopping deforestation in Papua as not to reduce raw materials. Importantly though, it develops interconnection and communication between Papuan women and Nature, which will later pass down knowledge from generation to generation so that the noken does not become extinct. It is also significant to develop this study from the perspective of deforestation in Papua and its impact on noken. It accommodates the exploration of scientific knowledge, especially about noken.[] 


\section{References}

Baharuddin, Alfini, B. Hari Wibisono, Budi Prayitno, and M. Sani Roychansyah. 2015. "Heterogenity of Amber and Komin in Shaping Settlement Pattern of Jayapura City." Komunitas: International Journal of Indonesian Society and Culture 7(2):324-32. doi: 10.15294/komunitas.v7i2.3287.

Batlajery, Semuel, and Caecilia Heny Setya Wati. 2019. "Development Strategy of Noken Product on Local Community in Sota Merauke." International Journal of Social Science and Business 3(2):145-53. doi: 10.23887/ijssb.v3i2.17587.

Bobii, Silfester. 2019. "Makna Teologis Noken dalam Budaya Orang Mee." Jurnal Teologi Kontekstual Fides et Ratio 4(2):51-74. doi: 10.47025/fer.v4i2.3.

Brauchler, Birgit. 2014. "Modes of Belonging in West Papua: Local Symbolism, National Politics and International Cultural Concepts." RIMA: Review of Indonesian and Malaysian Affairs 48(1):35-66.

Cahyadi, Anggoro, Damarjati Kun Marjanto, Hubertus Sadirin, Titus Pikei, Suci Paresti, Maria Listiyanti, Apriyanti Wulandari, Dewi Sri Handayani N, Nur Berlian, Ihya Ulumuddin, Kasiyanto Kasiyanto, and Suyud Winarno. 2013. Modul Pengembangan Muatan Lokal Noken. Jakarta: Direktorat Internalisasi Nilai dan Diplomasi Budaya Direktorat Jendral Kebudayaan Kementerian Pendidikan dan Budaya.

Creswell, John W. 2007. Research Design: Qualitative, Quantitative and Mixed Method Aproaches. London: SAGE Publications Ltd.

Dekme, Dedi. 2015. "Pengrajin Noken Pada Suku Bangsa Amungme di Desa Limau Asri Kecamatan Iwaka Kabupaten Mimika Provinsi Papua." Holistik: Journal of Social and Culture 8(16).
Dewi, Machya Astuti, Meilan Sugiarto, Iva Rachmawati, and Sri Issundari. 2018. "Noken: Women Empowerment a Tourism Industry in Papua." in Proceedings of the 5th International Conference on Community Development (AMCA 2018). Paris: Atlantis Press.

dil/wen. 2019. “Lestarikan Noken, Pemkot Terima Penghargaan.” Cenderawasih Pos. Retrieved (http://cenderawasihpos.co.id/lestarikannoken-pemkot-terima-piagampenghargaan/).

Iek, Mesak, and Sarlota Arrang Ratang. 2020. "Perception of Creative Economy in Supporting Family Economy In Jayapura City." Advances in Social Sciences Research Journal 7(4):351-59. doi: 10.14738/assrj. 74.8068.

Irianto, Agus Maladi. 2016. "Komodifikasi Budaya di Era Ekonomi Global terhadap Kearifan Lokal: Studi Kasus Eksistensi Industri Pariwisata dan Kesenian Tradisional di Jawa Tengah." Jurnal Theologia 27(1):21236. doi: 10.21580/teo.2016.27.1.935.

Istiqomah, Nurul, Dg Pabalik, and Nur Hidaya. 2019. "Eksistensi Noken dalam Modernisasi pada Masyarakat di Kota Sorong." Jurnal Faksi: Ilmu Sosial dan Ilmu Politik 4(2):1-16.

Januar, Arie. 2017. “Fungsi, Makna, dan Eksistensi Noken sebagai Simbol Identitas Orang Papua." Patrawidya: Seri Penerbitan Penelitian Sejarah dan Budaya 8(1):57-69.

Juniati, Wike. 2019. “Noken Literation: A Wisdom Local in Improving Investment Awareness Communities." Airlangga International Journal of Islamic Economics and Finance 2(2):105-22. doi: 10.20473/aijief.v2i2. 20642.

Kanem, Veronika, and Adele Norris. 2018. "An Examination of the Noken and Indigenous Cultural Identity: Voices of Papuan Women." Journal of Cultural Analysis and 
Social Change 3(1):1-12. doi: 10.20897/ jcasc/86189.

Kluckhohn C. 1953. Universal Categories of Culture. Anthropology Today. Chicago: University of Chicago Press.

Koentjaraningrat. 1987. "Anthropology in Indonesia." Journal of Southeast Asian Studies 18(2):217-34. doi: 10.1017/ S002246340002052X.

Koentjaraningrat. 2010. Manusia dan Kebudayaan di Indonesia. Jakarta: Djambatan.

Malak, Stepanus, and Nugraha Nugraha. 2012. Otonomi Khusus Papua. Arraafi.

Marit, Lenny Elisabeth. 2018. "Noken dan Perempuan Papua: Analisis Wacana Gender dan Ideologi." Melanesia: Jurnal Ilmiah Kajian Bahasa dan Sastra 1(1):33-42. doi: 10.30862/jm.v1i1.736.

Marit, Lenny Elisabeth, and Hugo Warami. 2015. "Bahasa, Sastra, dan Pembelajaran sebagai Basis Industri Kreatif." pp. 902-8 in Noken Papua: Sumber Industri Kreatif Komunitas di Tanah Papua. Jakarta: Universitas Negeri Jakarta.

Mosco, Vincent. 1996. The Political Economy of Communication: Rethinking and Renewal. London: SAGE Publications Ltd.

Mosco, Vincent. 2009. The Political Economy of Communication. 2nd ed. California: SAGE Publications Ltd.

Pekei, Titus. 2013. Cermin Noken Papua: Perspektif Kearifan Mata Budaya Papuani. Nabire: Ecology Papua Institute.

Pratitaswari, Anindita. 2018. "Democratic Election of Noken in Papua." Law Research Review
Quarterly 4(3):507-22. doi: 10.15294/ snh.v4i03.26986.

Ramah, Ramah. 2019. "Berharap Noken Bisa Menggantikan Kantong Plastik" ed. S. Syofiardi. Jubi.Co.Id. Retrieved (https://jubi. co.id/berharap-noken-bisa-menggantikankantong-plastik/).

Ransta, L. Lekatompessy. 2018. “Mama-Mama' in Papua and the Access to Market." p. 08015 in E3S Web of Conferences. Vol. 73, ed. Hadiyanto, Maryono, and B. Warsito.

Risamasu, P. I. M., M. Kaok, S. Siman, and N. Kadir. 2019. "Potential of Noken as Part of a Creative Economy in Improving the Economy of Indigenous Papuans." IOP Conference Series: Earth and Environmental Science 343:012221. doi: 10.1088/17551315/343/1/012221.

Ronsumbre, Nelwan. 2019. "Sistem Noken Papua: Manifestasi Demokrasi Berbasis Kearifan Lokal." Sospol: Jurnal Sosial Politik 5(2):261-76. doi: 10.22219/sospol.v5i2. 7388.

Syufi, Yafed, Made Budiarsa, I. Wayan Simpen, and Made Sri Satyawati. 2019. "The Portrait of Noken as a Manifestation of the Existence of Papuans." E-Journal of Linguistics 13(2): 303-13. doi: 10.24843/e-jl.2019.v13.i02. p09.

Warsito, H. R. 2012. Antropologi Budaya. Yogyakarta: Penerbit Ombak.

Weber, Max. 2005. The Protestant Ethic and The Spirit of Capitalism. London: Taylor \& Francis e-Library. 